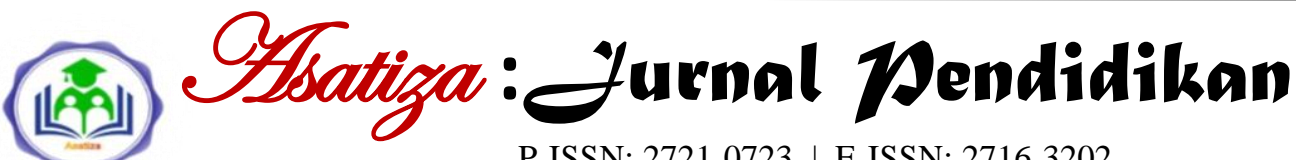 \\ P-ISSN: 2721-0723 | E-ISSN: 2716-3202 \\ https://ejournal.stai-tbh.ac.id/index.php/asatiza
}

\section{Implementasi Budaya Religius dalam Upaya Meningkatkan Kecerdasan Spiritual Peserta Didik}

\author{
Ma'mun Zahrudin ${ }^{1}$, Shalahudin Ismail ${ }^{2 *}$, Uus Ruswandi ${ }^{3}$, Bambang Samsul Arifin ${ }^{4}$ \\ ${ }^{1,2,3,4}$ Program Doktoral Ilmu Pendidikan Islam UIN Sunan Gunung Djati, Bandung, Indonesia
}

\section{INFORMASI \\ ARTIKEL

$\begin{array}{ll}\text { Histori Artikel: } \\ \text { Diterima } & : 20 / 01 / 2021 \\ \text { Direvisi } & : 06 / 04 / 2021 \\ \text { Disetujui } & : 03 / 05 / 2021 \\ \text { Diterbitkan } & : 25 / 05 / 2021\end{array}$

Keywords:

Implementation,

Religious Culture,

Spiritual Intelligence

Kata Kunci:

Implementasi, Budaya

Religius, Kecerdasan

Spiritual

\section{DOI:}

https://doi.org/10.46963/

asatiza.v2i2.293

\section{*Correspondence}

Author:

kosmakc2016@gmail.co $\underline{\mathrm{m}}$

\begin{abstract}
This study aimed at describing how the implementation of religious culture in increasing the spiritual intelligence of participants in schools. This study used a qualitative descriptive method with the objectives being studied were students of MI Terpadu Ad-Dimyati Bandung. The data collection techniques used were interviews, observation, and documentation. The results showed that the implementation of religious culture in increasing the spiritual intelligence of students through smiling, greeting, and greeting (3S), Tausiah, reading short surahs, and Asmaul Husna, prayer zuhr in the congregation, Dhuha prayer, Istighasah, and Infaq (Gerakan Dua Bumi-The movement of Two Earths) have met the criteria for increasing the spiritual intelligence of students. Because as an Islamic educational institution, the school is not only concerned with cognitive aspects but also good habituation and spiritual concepts that can be applied in everyday life. This research is expected to broaden the writer's insight, especially and generally for readers. Whereas for schools the implementation of religious culture to improve the spiritual intelligence of students should involve the participation of families and communities so that the increase in spiritual intelligence is more optimal.
\end{abstract}

\begin{abstract}
Abstrak
Penelitian ini bertujuan untuk mendeskripsikan bagaimana implementasi budaya religius dalam meningkatkan kecerdasan spiritual peserta di sekolah. Penelitian ini menggunakan metode deskriptif kualitatif dengan sasaran yang diteliti siswa MI Terpadu Ad-Dimyati Bandung. Adapun teknik pengumpulan data yang digunakan adalah wawancara, observasi, dan dokumentasi.. Hasil penelitian menunjukkan bahwa implementasi budaya religius dalam meningkatkan kecerdasan spiritual peserta didik melalui kegiatan senyum, sapa, dan salam (3S), tausiah, pembacaan surahsurah pendek dan asmaul husna, shalat dzuhur berjamaah, shalat dhuha, istighasah, dan infak gerak dua bumi telah memenuhi kriteria peningkatan kecerdasan spiritual peserta didik. Karena sebagai lembaga pendidikan Islam, sekolah tersebut tidak hanya mementingkan aspek kognitif saja, melainkan juga pembiasaan yang baik dan konsep spiritual yang dapat diaplikasikan dalam kehidupan sehari-hari. Penelitian ini diharapkan dapat menambah wawasan penulis khususnya dan umumnya bagi pembaca. Sedangkan bagi sekolah implementasi budaya religius dalam upaya meningkatkan kecerdasan spiritual peserta didik hendaknya melibatkan peran serta keluarga dan masyarakat sehingga peningkatan kecerdasan spiritual peserta didik semakin optimal.
\end{abstract}

\section{Cara mensitasi artikel:}

Zahrudin, M., Ismail, S., Ruswandi, U., \& Arifin, B. S. (2021). Implementasi budaya religius dalam upaya meningkatkan kecerdasan spiritual peserta didik. Asatiza: Jurnal Pendidikan, 2(2), 98-109. https://doi.org/10.46963/asatiza.v2i2.293 


\section{PENDAHULUAN}

Krisis paling mendasar yang dihadapi oleh manusia modern adalah krisis spiritual. Perihal tersebut tampak secara jelas bahwa manusia modern lebih menonjolkan kepentingan ego masingmasing, lebih memikirkan urusan material, cita-cita dunia, pencapaian pendidikan setinggi mungkin guna menaklukkan kompetisi secara global. Sementara aspek spiritual sebatas berada di atas hamparan sajadah dan tempat ibadah. Akibatnya orientasi dan visi ketuhanan bukan sebagai benteng bagi kehidupan setiap manusia. Namun lebih menuruti tuntutan nafsu dan syahwat sesuai keinginan hati (Aziz, 2017).

Beberapa peristiwa yang mewarnai realitas dunia pendidikan, mulai dari kondisi moral remaja dan generasi muda khususnya tampak makin memprihatinkan yang belum mampu menumbuhkan kader bangsa yang mempunyai karakter, religius, mandiri dan anti korupsi. Tawuran pelajar banyak terlihat di sana sini, perilaku kriminal, dan berbagai perbuatan yang a moral dewasa ini banyak dilakukan para pelajar (Rahmawati, 2016). Hal tersebut sebagai bukti praktik pendidikan yang ada belum mampu menyentuh secara keseluruhan, domain akal dan terutama menyentuh jiwa dan hati mereka, sehingga terlihat orientasi pengembangan intelektual menjadi prioritas utama dari suatu pendidikan, dan tanpa diimbangi dengan kekuatan spiritual.

Realitas tersebut mendorong timbulnya berbagai gugatan terhadap efektivitas pendidikan agama yang selama ini dipandang oleh sebagian besar masyarakat telah gagal, sebagaimana penilaian Mochtar Buchori bahwa kegagalan pendidikan agama ini disebabkan karena praktik pendidikannya hanya memperhatikan aspek kognitif semata dari pertumbuhan nilai-nilai (agama), dan mengabaikan pembinaan aspek afektif dan konatif-volitif, yakni kemauan dan tekad untuk mengamalkan nilai-nilai ajaran agama (Turmudi, 2018).

Padahal dalam Undang-undang Sistem Pendidikan Nasional No. 20 Th 2003 dinyatakan dengan tegas bahwa pendidikan adalah usaha sadar dan terencana untuk mewujudkan suasana belajar dan proses pembelajaran agar peserta didik secara aktif mengembangkan potensi dirinya untuk memiliki kekuatan spiritual keagamaan, pengendalian diri, kepribadian, kecerdasan, akhlak mulia, serta keterampilan yang diperlukan dirinya, masyarakat, bangsa, dan negara" (Imaddudin, 2015).

Pendidikan merupakan sebuah kunci keberhasilan generasi-generasi yang memiliki sifat beradab. Tanpa adanya pendidikan suatu bangsa dan negara ini tidak akan bisa berkembang. Di belahan dunia ini, bahkan daerah yang jauh dari pendidikan bisa dikatakan jauh dari nuansa beradab, bahkan bisa dikatakan kurang beradap. Apalagi yang tidak pernah kenal dengan pendidikan, yang sudah mengenali pendidikan saja masih ada yang jauh dari kata beradab. Arti penting dari kata pendidikan, yang membuat manusia semakin beradab. Oleh sebab itu pendidikan harus dimulai dari sedini mungkin (Karolina dkk., 2020).

Pada dasarnya, setiap sekolah memiliki tujuan yang sama yaitu 
mengembangkan kecerdasan peserta didik yang meliputi kecerdasan intelektual (IQ), kecerdasan emosional (EQ) dan kecerdasan spiritual (SQ) dengan berbagai pengajaran yang diterapkan di sekolah tersebut. Manusia membutuhkan ajaran agama yang mampu memenuhi kehausan rohaniahnya agar menjadikan penyejuk bagi jiwa dan pikirannya supaya setiap perilaku tetap dalam garis Ilahi yang dikenal dengan spiritualitas. Spiritualitas merupakan sebuah kata dari kata spirit yang berarti roh, kata ini juga berasal dari kata "spiritus" yang berarti bernafas. Dengan demikian, spiritual bisa diartikan sebagai roh dan nafas yang berfungsi sebagai energi kehidupan yang membuat seseorang menjadi hidup. Meravigliya menjelaskan dua dimensi spiritual yang mencerminkan pada nilai-nilai utama, yakni dimensi vertikal yang menghubungkan seseorang dengan tuhan dan dimensi horizontal yang berhubungan dengan alam (Hasim \& Nurfalah, 2020).

Pendidikan diarahkan kepada pembentukan manusia yang berguna. Sedangkan pengajaran adalah salah satu alat atau usaha untuk membentuk manusia tersebut. Pendidikan bertujuan meningkatkan kualitas manusia Indonesia. Manusia Indonesia yang berkualitas ialah manusia yang beriman dan bertakwa kepada Tuhan Yang Maha Esa, berbudi pekerti luhur, berkepribadian, berdisiplin, bekerja keras, tangguh dan bertanggung jawab, mandiri, cerdas dan terampil serta sehat jasmani dan rohani (Yasmansyah. 2019).

Dalam pendidikan agama, sikap ketaatan kepada Allah sangat ditekankan. Pendidikan agama untuk membentuk pribadi muslim yang religius. Pribadi muslim merupakan sebuah proses ketundukan seseorang terhadap seluruh perintah Allah. Dalam Al-Quran, Allah memerintahkan kepada orang-orang beriman untuk memasuki Islam secara kaffah/keseluruhan. Sebagaimana Firman Allah dalam Surah Al-Baqarah [2]: 208: "Wahai orang-orang yang beriman! Masuklah ke dalam Islam secara keseluruhan, dan janganlah kamu ikuti langkah-langkah setan. Sungguh, ia musuh yang nyata bagimu."(Arifin, 2012)

Untuk itu, di sekolah perlu adanya pembiasaan melalui bimbingan Islami terhadap peserta didik yaitu proses pemberian bantuan terhadap individu agar mampu hidup selaras dengan ketentuan dan petunjuk Allah, sehingga dapat mencapai kebahagiaan hidup di dunia dan akhirat. Dengan menyadari eksistensinya sebagai makhluk Allah yang demikian itu, berarti yang bersangkutan dalam hidupnya akan berperilaku yang tidak keluar dari ketentuan dan petunjuk Allah, dengan cara hidup yang demikian maka akan tercapai kehidupan yang bahagia dunia dan akhirat. Bimbingan keagamaan berbasis spiritualitas sangat diperlukan untuk mendapatkan arti hidup yang lebih dalam mengembangkan hubungan yang lebih responsif dengan Allah SWT. Terdapat dua dimensi yang berkaitan dengan kewajiban manusia, yaitu dimensi vertikal dan dimensi horizontal. Dimensi vertikal menuntut manusia membangun hubungan yang baik dengan sang khalik dan dimensi horizontal yang menuntut kesadaran untuk membangun akhlak yang baik dengan sesama manusia (Kinanti, Effendi, dan Mujib, 2019). 
Dalam upaya menginternalisasikan nilai-nilai religius pada diri peserta didik sehingga tercermin dalam diri mereka. Maka diperlukan strategi dalam penerapan internalisasi budaya religius dengan melakukan pola pembiasaan dalam sebuah budaya sekolah. Menurut Kholis Madjid religius atau agama bukan hanya kepercayaan pada yang ghaib dan melaksanakan ritual-ritual tertentu. Agama adalah keseluruhan tingkah laku manusia yang terpuji, yang dilakukan demi memperoleh ridha Allah. Manusia pada dasarnya menyukai nilai-nilai positif seperti jujur, amanah, takwa dan lainnya. Sebagai makhluk sosial, manusia juga tergantung pada lingkungannya sehingga menginginkan adanya kerja sama dengan orang lain di sekitarnya. Oleh karena itu, manusia terdorong untuk mewujudkan sifat-sifat yang dimilikinya tersebut dengan berpegang teguh pada nilai-nilai moral sebagai nilai utama yang akan memandunya. Kecenderungan untuk melaksanakan nilai moral juga berhubungan erat dengan upaya manusia dalam mencari kebenaran. Saat kebenaran filosofis dan kebenaran ilmiah berada pada ranah kognitif, maka moral berada pada ranah efektif. Adapun tolak ukur kebenaran ranah kognitif adalah benar ataupun salah, sedangkan kebenaran moral terkait dengan sikap dan perilaku yang tolak ukurnya adalah baik dan buruk (Kutisah, dkk., 2019).

Dengan demikian dapat dipahami bahwa budaya religius merupakan suatu kebiasaan yang dilakukan oleh warga sekolah yang dicerminkan dalam bentuk sikap atau perilaku yang didasarkan atas ajaran agama Islam. Sehingga, lingkungan sekolah menjadi lingkungan yang kental dengan nilai-nilai agama Islam. Dengan teori yang sudah ada dari berbagai pendapat tentang implementasi budaya religius, Madrasah Ibtidaiyah (MI) Terpadu Ad-Dimyati Kota Bandung sudah dari awal berdiri menerapkan budaya religius sekolah serta pengembangan kualitas PBM secara bertahap dilaksanakan sesuai dengan konsep awal sekolah tersebut dengan sistem Boarding School. Berdasarkan dari observasi yang penulis lakukan, penulis melihat bahwa budaya religius sekolah sudah terbentuk sejak sekolah ini berdiri. Kalau dilihat secara logika luar biasa program dan kinerja guru untuk menerapkan budaya religius sekolah, sebagai sekolah yang memiliki kegiatan-kegiatan keagamaan yang tinggi, semuanya itu terlaksana dapat di ukur dari kinerja guru. Akan tetapi dalam penerapannya, budaya religius sekolah ini sangat berbeda dengan sekolah atau Madrasah yang lebih banyak materi pembinaan budaya religius atau budi pekerti peserta didik.

Terdapat penelitian terdahulu mengenai implementasi budaya religius antara lain: Penelitian Siswanto (2019). Berjudul Pentingnya Pengembangan Budaya Religius di Sekolah. Penelitian (Fathurrohman, 2016). Berjudul Pengembangan Budaya Religius dalam Meningkatkan Mutu Pendidikan Bangsa. Penelitian Nadziroh (2020). Berjudul Strategi Penguatan Budaya Religius dalam Membentuk Karakter Peserta Didik Di Madrasah. Perbedaan penelitianpenelitian tersebut dengan penelitian peneliti adalah dari segi objeknya. 
Berdasarkan pemaparan di atas, maka tujuan penelitian ini adalah untuk mengetahui bagaimana implementasi budaya religius dalam upaya meningkatkan kecerdasan spiritual peserta didik di sekolah. Adapun manfaatnya adalah bahwa penelitian ini diharapkan dapat memberikan masukan dalam pengembangan ilmu pengetahuan khususnya mengenai peningkatan kecerdasan spiritual peserta didik melalui budaya religius. Serta diharapkan dari hasil penelitian ini dapat menambah wawasan khususnya bagi penulis umumnya bagi pembaca.

\section{METODE}

Penelitian ini menggunakan metode deskriptif kualitatif dengan sasaran yang diteliti siswa MI Terpadu Ad-Dimyati Bandung. Adapun teknik pengumpulan data yang digunakan adalah wawancara, observasi, dan dokumentasi. Data ini didapatkan dengan cara mengikuti kegiatan informan melalui rekaman dengan menggunakan kamera handphne lalu mentranskripkannya ke dalam tulisan sehingga dapat dianalisa dan ditindaklanjuti. Teknik wawancara dilaksanakan terhadap sasaran pendukung dalam penelitian ini yaitu wali kelas. Dimana objek yang diteliti merupakan suatu permasalahan yang dialami dan dijadikan target penelitian (Lathifah \& Rusli, 2019). Peneliti melakukan pemantauan dan terlibat dalam proses pembiasaan di sekolah tersebut. Teknik penelitian ini menggunakan triangulasi data, peneliti membandingkan hasil wawancara dengan observasi untuk mengecek kebenaran informasi yang didapatkan. Setelah data terkumpul, terdapat beberapa tahapan yang dilakukan peneliti, yaitu tahapan observasi, wawancara, dan kajian.

\section{HASIL DAN PEMBAHASAN Budaya Religius}

Dalam konteks sekolah budaya religius merupakan pelaksanaan suasana atau iklim kehidupan keagamaan yang dampaknya ialah terlaksanakannya suatu pandangan hidup yang bernafaskan atau dijiwai oleh nilai-nilai ajaran agama Islam yang biasa diwujudkan di sekolah. Dengan kata lain budaya religius adalah sekumpulan tindakan yang diwujudkan dalam perilaku, tradisi, kebiasaan seharihari dan simbol-simbol yang dipraktekkan berdasarkan agama oleh kepala sekolah, guru, petugas administrasi, peserta didik dan masyarakat sekolah. Sebab itu budaya religius tidak hanya berbentuk simbolik semata sebagaimana yang tercermin di atas, tetapi dirasakan penuh dengan nilainilai. Budaya religius juga tidak hanya muncul begitu saja, tetapi melalui proses pembudayaan (Wasito \& Turmudi, 2018).

Pendidikan nilai religius merupakan awal dari pembentukan budaya religius. Tanpa adanya pendidikan nilai religius, maka budaya religius dalam lembaga pendidikan tidak akan terwujud. Pendidikan nilai religius mempunyai posisi yang penting dalam upaya mewujudkan budaya religius. Karena hanya dengan pendidikan nilai religius, anak didik akan menyadari pentingnya nilai religius dalam kehidupan. Namun terdapat berbagai kendala dalam pendidikan nilai religius (Suyitno, 2018).

Dengan menjadikan agama sebagai tradisi dalam sekolah maka secara sadar maupun tidak ketika warga sekolah 
mengikuti tradisi yang telah tertanam tersebut sebenarnya warga sekolah telah melakukan ajaran Islam. Budaya religius di sekolah dapat dilakukan dengan beberapa cara, yakni melalui kepala sekolah, kegiatan belajar mengajar, ekstrakurikuler, dan juga tradisi perilaku warga sekolah yang dilaksanakan secara konsisten di lingkungan sekolah. Dan itulah yang akan membentuk religius culture (Sa'diah, 2019).

Frazer mengartikan agama, sebagaimana dikutip Nuruddin adalah sistem kepercayaan yang tidak stagnan dan berkembang sesuai dengan tingkat kognisi seseorang. Clifford Geertz mengemukakan, sebagaimana dikutip Roibin, agama dan spirit itu beda sedangkan spirit adalah semangat, pada dasarnya telah terjadi hubungan yang akrab antara agama sebagai sumber nilai dan agama sebagai sumber kognitif atau pengetahuan. Pertama, agama merupakan dasar bagi tindakan manusia (pattern for behaviour). Sebagai dasar tindakan agama menjadi arah bagi tindakan manusia. Kedua, agama merupakan pola dari tindakan manusia (pattern of behaviour). Sebagai pola ini agama dianggap sebagai hasil dari cipta, rasa dan karsa manusia yang tidak jarang telah dipengaruhi oleh kekuatan mistis (Rifa'i, 2016).

Muhaimin menyatakan bahwa strategi untuk membudayakan nilai-nilai agama di madrasah dapat dilakukan melalui : (1) Power strategi, yakni strategi pembudayaab agama di madrasah dengan cara menggunakan kekuasaan atau melalui people's power, dalam hal ini peran kepala madrasah dengan segala kekuasaannya sangat dominan dalam melakukan perubahan; (2) persuasive strategy, yang dijalankan lewat pembentukan opini dan pandangan masyarakat warga madrasah; dan (3) normative re-educative. Artinya norma yang berlaku di masyarakat termasyarakatkan lewat education, dan mengganti paradigm berpikir masyarakat madrasah yang lama dengan yang baru. Pada strategi pertama tersebut dikembangkan melalui pendekatan perintah dan larangan atau reward dan punishment. Sedangkan strategi kedua dan ketiga tersebut dikembangkan melalui pembiasaan, keteladanan, dan pendekatan persuasif atau mengajak pada warganya dengan cara yang halus, dengan memberikan alasan dan prospek baik yang bisa menyakinkan mereka (Siswanto, 2019).

Dengan demikian dapat disimpulkan bahwa fungsi budaya religius di sekolah adalah sebagai bimbingan yang mengarahkan dan menumbuhkan sikap iman dan takwa peserta didik kepada Allah yang diwujudkan dalam berbagai kegiatan keagamaan agar mampu mengendalikan diri dan menghilangkan sifat-sifat negatif yang melekat pada dirinya agar tidak sampai mendominasi dalam kehidupannya, serta melakukan sifat-sifat positif yang tercermin dalam kepribadiannya sehari- hari.

\section{Kecerdasan Spiritual}

Secara konseptual kecerdasan spiritual terdiri dari gabungan kata yaitu kecerdasan dan spiritual. Kecerdasan berasal dari kata cerdas yakni sempurnanya perkembangan akal budi untuk berpikir, mengerti atau tajam pikiran. Kecerdasan adalah pemahaman, kecepatan dan kesempurnaan sesuatu. 
Kecerdasan tidak hanya terbatas pada ketajaman berpikir otak saja, namun kecerdasan juga meliputi kemampuan memecahkan masalah-masalah yang abstrak (Hanyajani, 2017).

$$
\text { Zohar dan Marshal }
$$

berpendapat bahwa kecerdasan spiritual adalah kecerdasan yang bertumpu pada bagian dalam diri kita yang berhubungan dengan kearifan di luar ego atau jiwa sadar. Kecerdasan spiritual menjadikan manusia yang benar-benar utuh secara intelektual, emosi dan spiritual. Kecerdasan spiritual adalah kecerdasan jiwa. Kecerdasan spiritual dapat membantu manusia menyembuhkan dan membangun diri manusia secara utuh (Sabiq, 2012).

Kecerdasan spiritual (SQ) merupakan kecerdasan yang berpusat pada jiwa manusia, ia merupakan kecerdasan yang bisa menjadikan manusia pada hakikaat kehidupan manusia secara utuh dengan sempurna (Rohmah dan Hanif, 2019). Pengertian "manusia seutuhnya" adalah manusia yang berkembang ketiga aspek dalam dirinya, yaitu aspek intelligence quotient (IQ), emotional quotient $(E Q)$ dan spiritual quotient $(S Q)$. Dari ketiga aspek ini, pengembangan SQ bertujuan untuk membangun mental spiritual warga Indonesia yang kokoh, sehingga mereka memiliki integritas kepribadian yang baik yang dapat menunjang keberhasilan pembangunan (Kusuma, 2019).

Kecerdasan spiritual menjadi penting sekali dimiliki oleh tiap jiwa. Meskipun dalam rentang sejarah dan waktu yang panjang, manusia pernah mengagungkan kemampuan otak dan daya nalar (IQ). Kemampuan berpikir dianggap sebagai primadona. Potensi diri yang lain dimarginalkan. Pola pikir dan cara pandang yang demikian telah melahirkan manusia terdidik dengan otak yang cerdas tetapi sikap dan perilaku dan pola hidup sangat kontras dengan kemampuan intelektualnya. Banyak orang yang cerdas secara akademik tetapi gagal dalam pekerjaan dan kehidupan sosialnya. Mereka memiliki kepribadian yang terbelah (split personality) di mana tidak terjadi integrasi antara otak dan hati (Rahmawati, 2016).

Tanpa kecerdasan spiritual, seseorang akan mengalami kehampaan dalam hidupnya. Sebagaimana dikatakan oleh Amran bahwa kecerdasan spiritual melibatkan seperangkat kemampuan yang mamanfaatkan sumber daya rohani. Kecerdasan spiritual menekankan kemampuan yang menarik seperti adaptasi dan prediksi fungsi. Ia juga mendefinisikan kecerdasan spiritual sebagai kemampuan untuk menerapkan secara nyata dan mewujudkan sumber daya spiritual, nilai, dan kualitas untuk meningkatkan fungsi sehari-hari dan kesejahteraan ( Herlena \& Seftiani, 2018).

Dengan demikian dapat dipahami bahwa kecerdasan spiritual merupakan kecerdasan yang sudah ada dalam setiap manusia sejak lahir yang membuat manusia menjalani hidup dengan penuh makna, selalu mendengarkan suara hati nuraninya, tidak pernah merasa sia-sia, semua yang dijalaninya selalu bernilai. Dimana semua yang dijalaninya tidak hanya berdasarkan proses berfikir rasio saja tapi juga menggunakan hati nurani. 
Ma'mun Zahrudin, dkk

Implementasi Budaya Religius dalam Meningkatkan Kecerdasan Peserta Didik di MI Terpadu Ad-Dimyati Bandung

Budaya religius di sekolah berfungsi sebagai bimbingan yang mengarahkan dan menumbuhkan sikap iman dan takwa peserta didik kepada Allah yang diwujudkan dalam berbagai kegiatan keagamaan agar mampu mengendalikan diri dan menghilangkan sifat-sifat negatif yang melekat pada dirinya. Berdasarkan hasil wawancara dengan salah satu guru bahwa Madrasah Ibtidaiyah (MI) Terpadu Ad-Dimyati Kota Bandung sudah dari awal berdiri menerapkan budaya religius sekolah serta pengembangan kualitas PBM secara bertahap dapat dilaksanakan, sesuai dengan konsep awal sekolah tersebut dengan sistem Boarding School. Kegiatan seperti salam, senyum, dan sapa (3S), taushiah, hafalan surat-surat pendek, pembacaan do'a sebelum belajar, pelaksanaan sholat Dzuhur berjamaah, pelaksanaan shalat dhuha, istighasah, dan pengumpulan infaq (sedekah) yang disebut sebagai gerakan dua bumi yang dilaksanakan satu bulan sekali.

\section{Budaya Senyum, Sapa, dan Salam}

Berdasarkan hasil wawancara dengan salah satu guru bahwa budaya $3 \mathrm{~S}$ ini dilaksanakan setiap hari dimana seluruh guru yang dipimpin oleh kepala sekolah menyambut peserta didik di gerbang sekolah. Fungsinya adalah untuk memberikan pembelajaran kepada peserta didik mengenai pentingnya menjaga hubungan silaturrahim dan menjalin kekerabatan sebagai sebuah keluarga dengan guru, karyawan maupun teman melalui senyum, saling bertegur sapa dan mengucapkan salam untuk mendoakan kebaikan antar sesama. Melalui budaya tersebut, diharapkan peserta didik dapat merasakan kasih sayang yang sama di sekolah sebagaimana yang ia dapatkan dari orang tua dan keluarganya di rumah.

\section{Tausiah}

Hasil observasi menunjukkan bahwa dalam pelaksanaan kegiatan taushiah, guru menjadi penceramah secara bergantian sesuai jadwal yang telah ditetapkan. Kegiatan ini dilaksanakan di lapangan sebelum peserta didik masuk ke dalam kelasnya masing-masing yang diawali dengan kegiatan berdoa bersama. Materi yang disampaikan oleh guru kepada peserta didik mengenai pemberian motivasi untuk belajar serta bagaimana menerapkan keimanan dan ketaqwaan pada kehidupan sehari-hari saat di sekolah maupun di lingkungan sekitar tempat tinggal peserta didik. Dilanjutkan dengan penjelasan tentang akhlak baik dan akhlak buruk terhadap teman sebaya, sopan santun terhadap guru dan orang tua dan yang tidak kalah pentingnya selalu disampaikan kepada peserta didik untuk menjaga kebersihan lingkungan sekolah.

\section{Pembacaan Surat-Surat Pendek dan} Asmaul Husna

Budaya religius dalam meningkatkan kecerdasan spiritual peserta didik lainnya adalah pembacaan surat surat pendek dan asmaul husna yang dilaksanakan secara rutin setiap hari baik di lapangan sebelum masuk ke kelas maupun di dalam kelas sebelum proses pembelajaran dimulai dengan dipimpin oleh guru ataupun peserta didik secara bergiliran. Dampak positif dari budaya religius ini MI Terpadu Ad-Dimyati selalu 
mengutus perwakilanya untuk mengiuti lomba MTQ.

Hasil observasi dan wawancara dengan salah satu guru bahwa pembacaan surah-surah pendek dan asmaul husna tersebut disesuaikan dengan tingkatan kelasnya. Walaupun tidak semua peserta didik hafal sesuai dengan pedoman yang telah ditetapkan sekolah. Sehingga pihak sekolah bekerjasama dengan orang tua, supaya pembiasaan menghafal surahsurah pendek dan asmaul husana yang telah didapatkan di sekolah juga dapat dilakukan dan dilancarkan kembali di rumah atas arahan dan pengawasan orang tua. Lebih jauh, kegiatan ini juga mendapat tanggapan yang sangat positif dari orang tua peserta didik khususnya, karena kegiatan positif seperti ini dapat lebih memotivasi peserta didik untuk cepat menghafal dan mencintai al-Qur'an dan memahami maknanya. Dengan budaya membaca al-Qur'an di sekolah, peserta didik diharapkan dapat lebih meningkatkan keimanan dan ketaqwaan nya agar pribadi yang lebih baik dan tidak mudah terbawa lingkungan yang sudah teralihkan oleh globalisasi.

\section{Shalat Dhuha}

Hasil observasi menunjukkan bahwa shalat dhuha berjamah dilaksana kan setiap Jumat pagi di halaman sekolah yang dibimbing oleh salah satu guru secara bergiliran sesuai dengan jadwal yang telah ditentukan dan dilaksanakan sebelum melaksanakan kegiatan belajar mengajar di kelas.

\section{Shalat Dzuhur Berjamaah}

Hasil wawancara dengan kepala sekolah yang diperkuat dengan hasil observasi bahwa shalat dzuhur berjamaah dilaksanakan di lapangan sekolah. Dimana dengan membacakan sholawat sebelum adzan berkumandang, segala aktivitas di kelas harus diberhentikan. Guru menyerukan seluruh peserta didik untuk segera mengambil air wudhu dan segera berkumpul di lapangan sekolah untuk melaksanakan shalat dzuhur berjamaah. Lebih lanjut kepala sekolah menyatakan bahwa tujuan didakannya budaya shalat dzuhur berjamaah ini ialah memupuk kesadaran bahwa panggilan Allah harus disegerakan, menambah sikap disiplin serta menambah tingkat spiritual dan kedekatan peserta didik dengan Sang Pencipta. Dikarenakan dengan budaya shalat dzuhur berjamaah

Karena dengan terbiasa melaksanakan sholat di awal waktu, diharapkan peserta didik dapat membiasakan diri untuk selalu berdisiplin, bukan hanya dalam melaksanakan ibadah shalat, namun juga dalam pelaksanaan kegiatan dan aktifitas lain di sekolah dan di rumah. Sehingga berdampak baik terhadap peserta didik untuk mentaati peraturan atau komitmen-komitmen yang telah dibangun di sekolah dengan kesadaran peserta didik sendiri.

\section{Istighasah}

Hasil wawancara dengan salah satu guru MI Terpadu Ad-Dimyati Bandung, bahwa pelaksanaan istighasah ini bertempat di lapangan sekolah yang dilaksanakan setiap hari rabu dan harus diikuti oleh seluruh peserta didik. Kegiatan istighasah ini merupakan kegiatan yang cenderung banyak mengandung dimensi ibadah dan terdapat unsur bermunajat kepada Allah yang 
bertujuan untuk mengisi rasa percaya diri peserta didik.

\section{Infak Gerak Dua Bumi}

Infak gerak dua bumi ini dilaksanakan setiap minggu dengan jumlah yang telah ditentukan sebesar dua ribu rupiah untuk setiap peserta didik yang dikordinir oleh salah satu sesuai dengan yang telah ditetapkan bersama. Kegiatan infak tersebut dilaksanakan sebagai upaya mewujudkan sikap kedermawanan peserta didik. Adapun hasil infak menurut salah satu guru di MI Terpadu Ad-Dimyati sebagai penunjang pelaksanaan ibadah qurban yang dilaksanakan di sekolah.

Berdasarkan pembahasan tersebut di atas sangat jelas bahwa upaya yang dilaksanakan guna meningkatkan kecerdasan spiritual peserta didik telah dilaksanakan melalui beberapa kegiatan yang bertujuan mencetak generasigenerasi yang bukan hanya cerdas secara intelektual, namun juga memiliki kecerdasan emosional, sosial, dan kecerdasan spiritual yang baik, sehingga kelak dapat berkontribusi positif terhadap agama, keluarga, masyarakat, bangsa dan negara.

Hal-hal positif yang terlihat dari hasil budaya religius ini yaitu memiliki sikap terpuji, baik dalam perilaku maupun perkataan, sikap religius, jujur, mandiri, bertanggungjawab, disiplin, toleransi, cinta damai dan peduli sosial. Dengan demikian, dapat dikatakan bahwa budaya religius yang dicanangkan sebagai salah satu program unggulan di MI Terpadu AdDimyati Kota Bandung telah memenuhi kriteria peningkatan kecerdasan spiritual peserta didik. Karena sekolah sebagai lembaga pendidikan tidak hanya mementingkan aspek kognitif saja, melainkan juga pembiasaan yang baik dan konsep spiritual yang dapat diaplikasikan dalam kehidupan sehari-hari.

\section{SIMPULAN}

Budaya religius adalah sekumpulan tindakan yang diwujudkan dalam perilaku, tradisi, kebiasaan sehari-hari dan simbolsimbol yang dipraktikkan berdasarkan agama oleh kepala sekolah, guru, petugas administrasi, peserta didik dan masyarakat sekolah. Kecerdasan spiritual merupakan kecerdasan jiwa yang bertujuan untuk membangun mental spiritual peserta didik yang kokoh, sehingga mereka memiliki integritas kepribadian yang baik yang dapat menunjang keberhasilan pembangunan. Budaya religius yang dicanangkan sebagai salah satu program unggulan di MI Terpadu Ad-Dimyati Kota Bandung telah memenuhi kriteria peningkatan kecerdasan spiritual peserta didik. Karena sekolah tersebut sebagai lembaga pendidikan Islam tidak hanya mementingkan aspek kognitif saja, melainkan juga pembiasaan yang baik dan konsep spiritual yang dapat diaplikasikan dalam kehidupan sehari-hari.

\section{REFERENSI}

Arifin, Z. (2012). Pendidikan multikultural-religius untuk mewujudkan karakter peserta didik yang humanis-religius. Jurnal Pendidikan Islam, 1(1), 89-103. https://doi.org/10.14421/jpi.2011.11. 89-103.

Aziz, S. (2017). Pendidikan spiritual berbasis sufistik bagi anak usia dini dalam keluarga. Jurnal Dialogia, 15(1), 131-150. DOI: https://doi.org/10.21154/dialogia.v1 $5 \mathrm{i} 1.1188$. 
Fathurrohman, M. (2016). Pengembangan budaya religius dalam meningkatkan mutu pendidikan. Ta'allum: Jurnal Pendidikan Islam, 4(1), 19-42. https://doi.org/10.21274/taalum.201 6.4.1.19-42.

Hanyajani, A. N. (2017). Upaya Pembinaan Kecerdasan Spiritual Santri Pondok Pesantren Assalafiyah Nurul Yaqiin Kelurahan Bejen Karanganyar. IAIN Salatiga.

Hasim, F., \& Nurfalah, Y. (2020). Pendidikan spiritual dalam tradisi istighosah santri Pondok Pesantren Al Mahrusiyah III Ngampel. EL Bidayah: Journal of Islamic Elementary Education, 2(2), 89-100. https://doi.org/10.33367/jiee.v2i2.13 04.

Herlena, B., \& Seftiani, N. A. (2018). Kecerdasan spiritual sebagai prediktor kesejahteraan subjektif pada mahasiswa. Jurnal Psikologi Integratif, $\quad 6(1), \quad 101-115$. https://doi.org/10.14421/jpsi.v6i1.14 73.

Imaddudin, A. (2015). Mengembangkan kesejahteraan spiritual peserta didik sebagai katalis bangsa inovatif. Pedagogik (Jurnal Pendidikan Sekolah Dasar), 3(1), 51-61.

Kinanti, R. D., Effendi, D. I., \& Mujib, A. (2019). Peranan bimbingan keagamaan dalam meningkatkan kecerdasan spiritual remaja. Irsyad: Jurnal Bimbingan, Penyuluhan, Konseling, Dan Psikoterapi Islam, 7(2), 249-270. https://doi.org/10.15575/IRSYAD.V 7I2.58.

Karolina, A., Afsiska, W., Azwar, B., Cikdin, C., \& Yanuarti, E. (2020). Peran orangtua penambang emas dalam menanamkan pendidikan agama Islam pada anak dikelurahan kampung jawa. Edification Journal : Pendidikan Agama Islam, 3(1), 1-22. https://doi.org/10.37092/ej.v3i1.206.

Kusuma, W. (2019). Upaya meningkatkan prestasi belajar melalui peningkatan kecerdasan spiritual santri pondok pesantren. JOEAI:Journal of Education and Instruction, 2(2), 104111.

https://doi.org/https://doi.org/10.315 39/joeai.v2i2.896/

Kutisah, K., Sa'dijah, J., \& Faisol. A (2019). Implementasi budaya religius di SMA Islam Nusantara Malang. Vicratina: Jurnal Pendidikan Islam, 4(2), 36-41.

Lathifah, Z. K., \& Rusli, K. R. (2019). Pembiasaan spiritual untuk meningkatkan pendidikan karakter peserta didik. Jurnal Tadbir Muwahhid, 3(1), 14-26. http://dx.doi.org/10.30997/jtm.v3i1. 1649.

Nadziroh, A. (2020). Strategi penguatan budaya religius dalam membentuk karakter. Religious: Jurnal Studi Agama-Agama Dan Lintas Budaya, 1(4), 64-72. https://doi.org/10.15575/rjsalb.v4i1. 6432.

Rahmawati, U. (2016). Pengembangan kecerdasan spiritual santri: studi terhadap kegiatan keagamaan di Rumah TahfizQu Deresan Putri Yogyakarta. Jurnal Penelitian, 10(1). http://dx.doi.org/10.21043/jupe.v10i 1.1332 .

Rifa'i, M. K. (2016). Internalisasi nilainilai religius berbasis multikultural dalam membentuk insan KAMIL. Jurnal Pendidikan Agama Islam (Journal of Islamic Education Studies), $\quad 4(1), \quad$ 116-133. https://doi.org/10.15642/jpai.2016.4. 1.116-133.

Rohmah, L., Hanif, M., \& Anggraheni, I. (2019). Implementasi nilai-nilai kecerdasan spiritual di Yayasan Pondok Modern Al-Rifa'ie Satu 
Ma'mun Zahrudin, dkk

Malang. VICRATINA: Jurnal Pendidikan Islam, 4(4), 94-100.

Sabiq, Z. (2012). Kecerderdasan emosi, kecerdasan spiritual dan perilaku prososial santri Pondok Pesantren Nasyrul Ulum Pamekasan. Persona, Jurnal Psikologi Indonesia, 1(2), 5365.

https://doi.org/10.30996/persona.v1i 2.21 .

Sa'diah, M. (2019). Menggagas model implementasi kompetensi leadership guru PAI dalam mengembangkan budaya religius sekolah. Tawazun: Jurnal Pendidikan Islam, 12(2), 112.

https://doi.org/10.32832/tawazun.v1 $2 \mathrm{i} 2.2682$

Siswanto, H. (2019). Pentingnya pengembangan budaya religious di sekolah. Madinah: Jurnal Studi Islam, 6(1), 51-62. Retrieved from http://ejournal.iai-

tabah.ac.id/index.php/madinah/articl e/view/312.

Suyitno. (2018). Strategi Pembentukan Budaya Religius Untuk Meningkatkan Karakter Islami di Sekolah Dasar Muhammadiyah Wirobrajan 3 Yogyakarta. Edukasi: Jurnal Pendidikan, 10(2), 191-204.

Wasito, W., \& Turmudi, M. (2018). Penerapan budaya religius di SD Al Mahrusiyah. Tribakti: Jurnal Pemikiran Keislaman, 29(1), 1-22. https://doi.org/10.33367/tribakti.v29i 1.560 .

Yasmansyah, Y. (2019). Strategi guru PAI dalam penerapan budaya religius sekolah di SMA Negeri 3 Batusangkar. Al-Fikrah: Jurnal Manajemen Pendidikan, 6(2), 159172.

https://doi.org/10.31958/jaf.v6i1.138 